Europe's university system needs to be affordable as well as excellent. But there is scope for EC help with the mobility of academics towards universities judged to have excellence within their grasp.

How should this be done? The temptation to single out in advance a group of European universities for special treatment should be resisted. The result would be a series of political dogfights more intense than those provoked by last week's settlement of the row with the United States over oilseed production. What the EC needs, instead, is a scheme for awarding grants to institutions for academic innovations (often research projects) judged worthwhile by serious panels of referees and which, on that account, command the respect of the international community. That way, over time, the outstanding universities would emerge head and shoulders above the merely excellent. To lend piquancy to the recipe, grant-making should be extended not merely to candidate members of the EC, but to the universities of Poland, Czechoslovakia and Hungary, traditionally part of the European academic circus.

Sadly, this important issue is unlikely to be raised at the Edinburgh meeting of Europe's Council of Ministers two weeks from now. Indeed, on past EC form, it is unlikely ever to rate a well-informed discussion. That is the outcome most urgently to be avoided. Europe, nearly a millennium ago, invented the idea that groups of scholars might educate the young in their ways. (At Bologna, at the beginning, members of the faculty were appointed and paid by their students.) It would be a great pity if Europe now let slip the opportunity to make its universities its agents for the preservation of the old culture, for sometimes subversive social change and for creating the prosperity it repeatedly promises.

\section{His father's Oldsmobile}

The heads of the NSF and NIH in the United States have followed ways of plotting the future.

WiTh governments everywhere eager to harness science to economic development, last week's report on the future of the US National Science Foundation (NSF) is a timely warning of the limits of what is possible (see page 285). But the report also reveals important differences in style and substance between Walter Massey, the NSF director, and Bernadine Healy, the director of the US National Institutes of Health (NIH), who has been engaged in a similar review of her agency's future.

Both Massey and Healy, appointed well into the term of outgoing president George Bush and waiting to learn whether they will be replaced by president-elect Bill Clinton, believe strongly that their agencies should do more than serve the needs of their constituent popula- tions of scientists. But while Healy has spent 18 months on a highly publicized and at times controversial effort to produce a strategic plan that she has labelled Advantage America, Massey has achieved much the same with a minimum of fuss and without drawing unfavourable attention to himself or his agency.

Part of the difference lies in personalities: Healy seems to relish confrontation, Massey avoids it whenever possible. Thus when the director of the National Aeronautics and Space Administration told Congress that the space station Freedom would contribute significantly to basic biology by studying how astronauts function under microgravity, Healy replied immediately that more could be learned by increasing NIH's budget to study such processes on Earth. In contrast, when the US Senate told NSF to be more responsive to the needs of industry, Massey followed the prudent course of appointing a 15-member commission to study the issue.

Healy is fond of saying that business-as-usual is no longer good enough and that NIH must change. She has even adapted a popular commercial for Oldsmobile motor-cars that emphasizes how the automobile has been redesigned to appeal to a younger audience, telling researchers around the United States that "this is not your father's NIH". But even when biomedical researchers agree that change is needed, they resent being told that they are part of the problem, and they are confused by Healy's incessant criticism of a system that they feel has worked rather well for four decades. At the same time, there is grumbling within Congress that the strategic plan, begun shortly after Healy took office in April 1991, is languishing within the Department of Health and Human Services.

In contrast, Massey says that he is quite pleased with the commission's conclusion that there is nothing wrong with NSF and that no drastic changes are necessary. In other words, the agency is still his father's NSF, and he likes it that way. But he also agrees that NSF can work more closely with industry and he promises to increase industrial collaboration in the months ahead. His response is intended both to assure researchers that he is on their side and to tell Congress that he plans to listen carefully to its advice. Any disagreement can be ironed out, he says, especially if Congress sees fit to increase NSF's budget.

Clinton has not yet said whether he plans to replace either director - both serve at the pleasure of the president, although Massey officially has a six-year term of office that runs until 1996. In the end, the decision may come down to personal considerations. It would be wrong if the choice of the head of a strictly science agency was determined by political philosophy. Still, if one remains and one is sent packing, it may be well to remember that each handled differently their agency's attempt to plot its future.

NATURE · VOL $360 \cdot 26$ NOVEMBER 1992 